\title{
PERBANDINGAN DEFORMASI DINDING PADA BASEMENT METODE TOP-DOWN DENGAN ANALISIS CONSTRUCTION STAGE DAN ANALISIS KONVENSIONAL
}

\author{
Raynaldi $^{1}$ dan Alfred Jonathan Susilo ${ }^{2}$ \\ ${ }^{1}$ Program Studi Sarjana Teknik Sipil, Universitas Tarumanagara, Jl. Letjen S. Parman No.1 Jakarta \\ raynaldi.325179101@stu.untar.ac.id \\ ${ }^{2}$ Program Studi Sarjana Teknik Sipil, Universitas Tarumanagara, Jl. Letjen S. Parman No.1 Jakarta \\ alfredsusilo@gmail.com
}

Masuk: 05-01-2021, revisi: 14-01-2021, diterima untuk diterbitkan: 11-03-2021

\begin{abstract}
In basement construction with the top-down approach, excavation and slab installation work are carried out in stages. However, not all geotechnical applications can simulate construction stages, hence this effect has been ignored by many engineers in practice. Therefore, in this study, the effect of basement construction stages is analyzed using MIDAS GTS NX. In the program, two different analyses are performed. The first analysis is the construction stage analysis that simulates construction stages. As a comparison, a conventional analysis is performed which doesn't simulate construction stages. The two analysis results are compared. This analysis focuses mainly on the wall deformation. The modeling consists of 5 excavation stages (17 meters deep) and a diaphragm wall (36 meters deep). The walls are given 5 layers of slab reinforcements. In the first excavation stage, the maximum wall deformation results in both analyses show slightly different results (the construction stage analysis result is $8 \%$ greater than that of conventional analysis). However, in the final excavation stage, a significant difference is shown (the construction stage analysis result is 37\% greater than that of conventional analysis). These results indicate that the effect of construction stages should not be neglected, especially in multi-story basements with top-down construction.
\end{abstract}

Keywords: top-down; MIDAS GTS NX; construction stage; diaphragm wall; deformation

\begin{abstract}
ABSTRAK
Pada konstruksi basement dengan metode top-down, pekerjaan penggalian dan pemasangan pelat dilakukan secara bertahap. Namun, tidak semua aplikasi geoteknik dapat mensimulasikan tahapan konstruksi sehingga pengaruhnya sering diabaikan oleh banyak insinyur dalam praktiknya. Maka, pada penelitian ini dilakukan analisis pengaruh tahapan konstruksi basement menggunakan aplikasi MIDAS GTS NX. Pada program, akan dilakukan dua analisis yang berbeda. Pertama, dilakukan analisis construction stage yang mensimulasikan tahapan konstruksi. Sebagai perbandingan, dilakukan analisis konvensional yang tidak mensimulasikan tahapan konstruksi. Kedua hasil analisis dibandingkan. Analisis ini lebih berfokus pada deformasi yang terjadi pada dinding diafragma. Pemodelan terdiri dari 5 tahap galian dengan kedalaman 17 meter dan dinding diafragma dengan kedalaman 36 meter. Dinding diberi perkuatan pelat sebanyak 5 lapis. Pada galian tahap pertama, hasil deformasi maksimum dinding pada kedua analisis menunjukkan hasil yang tidak jauh berbeda (hasil analisis construction stage lebih besar $8 \%$ dibandingkan hasil analisis konvensional). Tetapi pada galian tahap akhir, hasil deformasi maksimum dinding pada kedua analisis menunjukkan perbedaan signifikan (hasil analisis construction stage lebih besar 37\% dibandingkan hasil analisis konvensional). Hasil ini menunjukkan bahwa pengaruh tahapan konstruksi sebaiknya tidak diabaikan khususnya pada basement bertingkat banyak dengan metode top-down.
\end{abstract}

Kata kunci: top-down; MIDAS GTS NX; tahapan konstruksi; dinding diafragma; deformasi

\section{PENDAHULUAN}

Pekerjaan galian tanah akan menimbulkan deformasi lateral pada dinding diafragma, sehingga perlu dilakukan analisis untuk memastikan keamanannya. Untuk mendapatkan hasil analisis yang akurat, maka perlu dilakukan analisis yang menyerupai kondisi sesungguhya. Dalam pekerjaan basement dengan metode top-down di lapangan, proses dilakukan secara bertahap mengikuti suatu tahapan konstruksi. Namun sayangnya, tidak semua aplikasi geoteknik dapat mensimulasikan tahapan konstruksi sesuai dengan yang dikerjakan di lapangan. Padahal, efek penerapan beban mati secara sekuensial merupakan faktor penting yang harus dipertimbangkan dalam analisis (Das, 2016). Sayangnya, efek ini telah diabaikan oleh banyak insinyur dalam praktiknya. Salah satu cara untuk mempertimbangkan efek ini dengan benar dalam analisis adalah dengan melakukan prosedur analisis langkah demi langkah sesuai dengan penerapan 
beban mati secara sekuensial selama konstruksi berlangsung atau biasa disebut analisis construction stage. Oleh karena itu, pada penelitian ini akan dilakukan analisis pengaruh tahapan konstruksi pada basement dengan metode top-down. Aplikasi MIDAS GTS NX digunakan untuk analisis.

Pada program, akan dilakukan dua analisis yang berbeda. Pertama, dilakukan analisis construction stage yang dapat mensimulasikan tahapan konstruksi. Kedua, dilakukan analisis konvensional yang tidak mensimulasikan tahapan konstruksi. Kedua analisis diilustrasikan pada Gambar 1. Kedua hasil analisis akan dibandingkan dan dianalisis seberapa besar pengaruh tahapan konstruksi. Analisis ini lebih berfokus pada deformasi yang terjadi pada dinding diafragma untuk mengetahui perubahan deformasi yang terjadi pada dinding penahan tanah selama tahapan konstruksi. Untuk batasan masalah pada penelitian ini, basement yang ditinjau adalah basement 5 tingkat dan analisis dilakukan pada kondisi tanah drained.
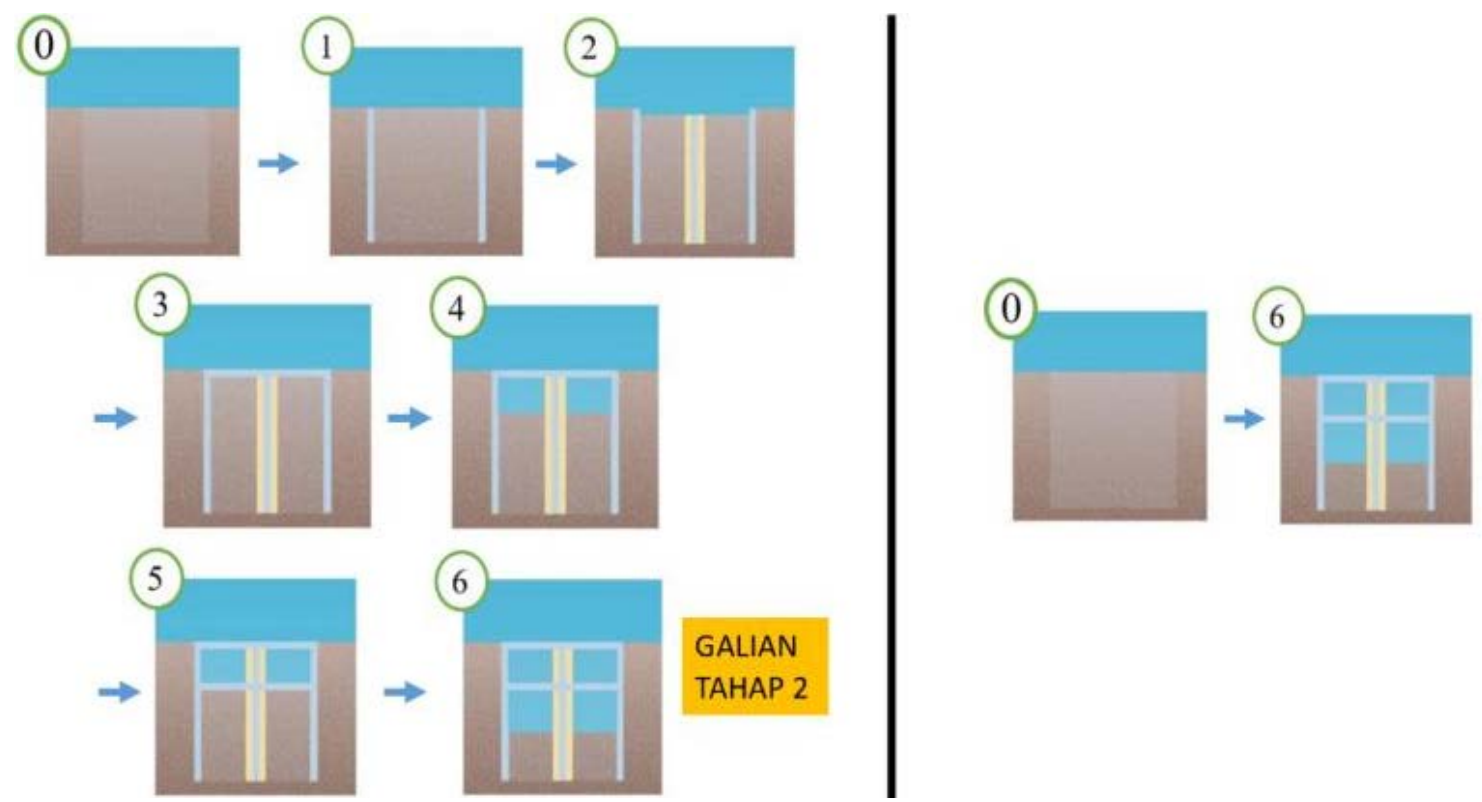

Gambar 1. Ilustrasi analisis construction stage (kiri) dan analisis konvensional (kanan)

\section{Metode Top-Down}

Metode membangun bangunan tinggi yang dilakukan secara bersamaan ke bawah dan ke atas dinamakan top-down. Pada metode konstruksi top-down, urutan pekerjaan tidak dimulai dari lantai basement paling bawah (dasar galian). Tepatnya, titik awal pekerjaan dimulai dari pelat lantai satu (ground level atau muka tanah). Kemudian, galian mengarah ke bawah dan secara bersamaan juga dilakukan pekerjaan struktur atas. Dalam hal ini terjadi proses pekerjaan ganda, yaitu ke bawah dan ke atas. Jika dibandingkan dengan sistem konvensional (bottom-up), penggunaan sistem top-down lebih menghemat biaya dan memangkas waktu pelaksanaan (Prawidiawati, 2015). Faktor hemat waktu dan biaya memungkinkan sistem top-down akan berkembang cepat dan menjadi pilihan para perencana.

\section{Tahapan Pada Metode Top-Down}

Tahapan pengerjaan basement dengan metode top-down dapat dilihat pada Gambar 2 di bawah dengan penjelasan sebagai berikut:

1. Pemasangan dinding diafragma

2. Pemasangan fondasi dan king post

3. Pembuatan pelat lantai dasar (dicor di atas tanah dengan lantai kerja). Disediakan lubang lantai dan ramp sementara untuk pembuangan tanah galian.

4. Penggalian basement tingkat 1

5. Pengecoran pelat lantai. Disediakan lubang lantai dan ramp sementara untuk pembuangan tanah galian

6. Penggalian basement tingkat 2 dilaksanakan seperti galian basement 1 , begitu seterusnya

7. Pengecoran raft foundation

8. King post dicor, sebagai kolom struktur 


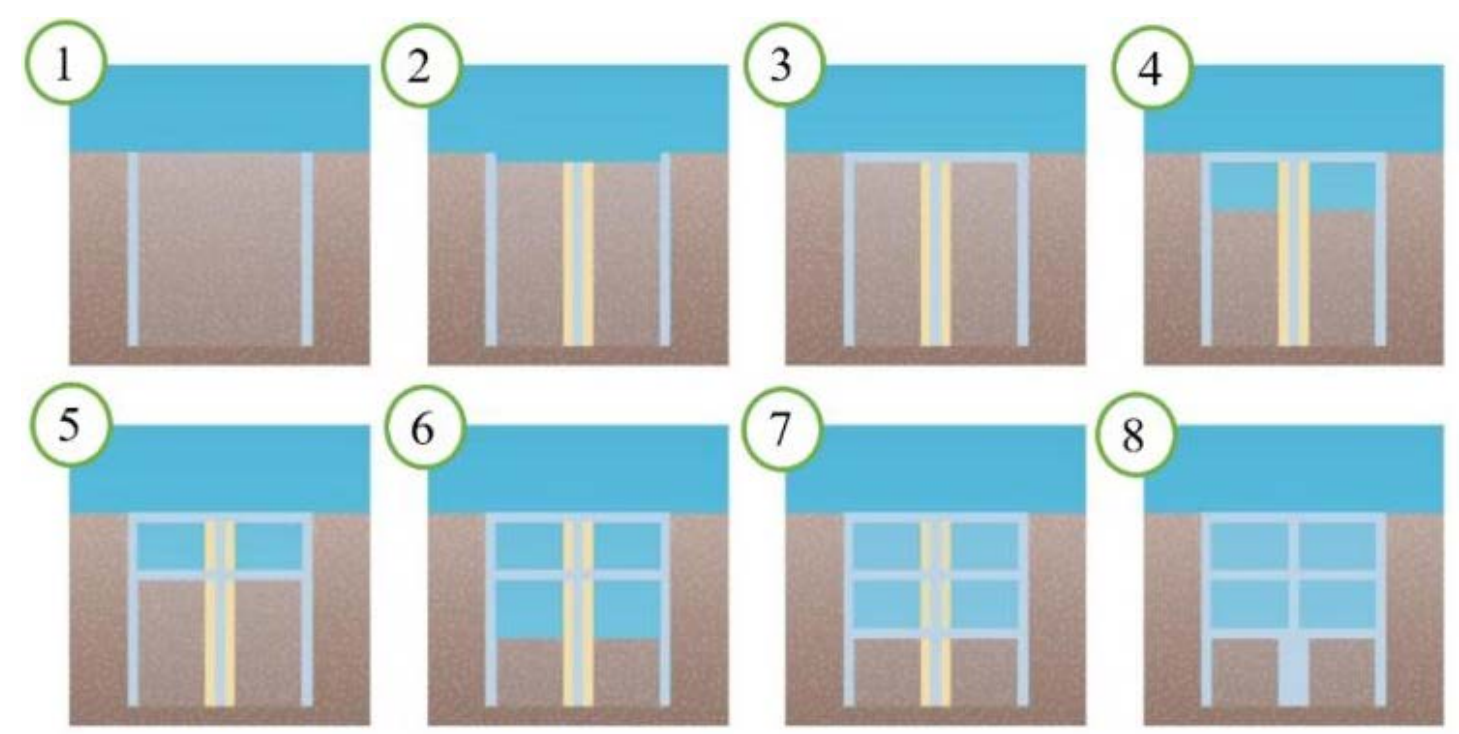

Gambar 2. Pekerjaan basement dengan sistem top-down

\section{Dinding Penahan Tanah}

Dinding penahan tanah yang digunakan pada basement metode top-down umumnya adalah dinding diafragma. Dinding diafragma atau dinding sekat adalah sebuah membran buatan dengan ketebalan (sesuai tebal alat penggali bernama grabber) dan kedalaman tertentu. Dinding diafragma merupakan dinding penahan tanah yang dipasang sebagai sebuah sistem pengembangan lebih lanjut dari sistem tiang bor beruntun atau secant pile dan juga contiguous pile. Penggunaan sistem dinding diafragma sangat ekonomis karena ada banyak faktor menguntungkan bila dibandingkan dengan sistem dinding penahan beruntun (Mistra, 2012).

\section{Tiang Bor}

Tahap pengeboran dikerjakan setelah dilakukan penetapan titik bor di lapangan sesuai rencana. Untuk menjaga kestabilan lubang, selama proses penggalian lubang yang dihasilkan selalu diisi dengan lumpur bentonite yang dikontrol kekentalan dan berat jenisnya sebelum dituangkan ke dalam lubang galian. Setelah lubang selesai dikerjakan pembesian dimasukkan diikuti dengan pengecoran dengan menggunakan pipa tremi. Selama proses pengecoran kualitas beton harus tetap dijaga.

\section{King Post}

King post merupakan langkah kerja setelah seluruh pekerjaan pemasangan dinding diafragma selesai, yang berfungsi sebagai (Mistra, 2012):

1. Kolom sementara yang mendukung pelat lantai basement atau strutting pada saat penggalian basement.

2. Menahan pelat lantai dan menyalurkan beban yang bekerja pada pelat lantai basement ke tiang fondasi dimana king post tertanam.

King post ini sangat berperan pada pelaksanaan sistem top-down yang memungkinkan pelaksanaan pembangunan serentak ke atas dan ke bawah.

\section{Pelat}

Selain berfungsi sebagai penahan beban gravitasi yang bekerja padanya, pelat lantai pada metode konstruksi top-down juga berfungsi penting sebagai pengaku (strut) yang menahan deformasi lateral dari dinding penahan tanah (Xiao, 2016). Hal yang juga perlu diperhatikan adalah rencana ketinggian lantai ke lantai dari pelat basement karena alat gali backhoe yang digunakan membutuhkan ruang gerak minimum tertentu. Bila jarak lantai terlalu dekat maka penggalian tidak dapat dilaksanakan secara berurutan, tapi harus meloncat satu lantai.

\section{Raft (Base Floor)}

Lantai dasar basement (base floor) merupakan fondasi utama dari seluruh bangunan sehingga dibuat berbeda dengan lantai basement lainnya. Pada lantai bagian ini merupakan lokasi adanya pile cap, fondasi tiang bor, dan kolom struktur utama. Seringkali didapat kebutuhan ruang pile cap yang hampir memenuhi seluruh ruang lantai basement bawah. Desain pelat ini sekaligus difungsikan sebagai pile cap yang lebar seperti pada Gambar 3. 


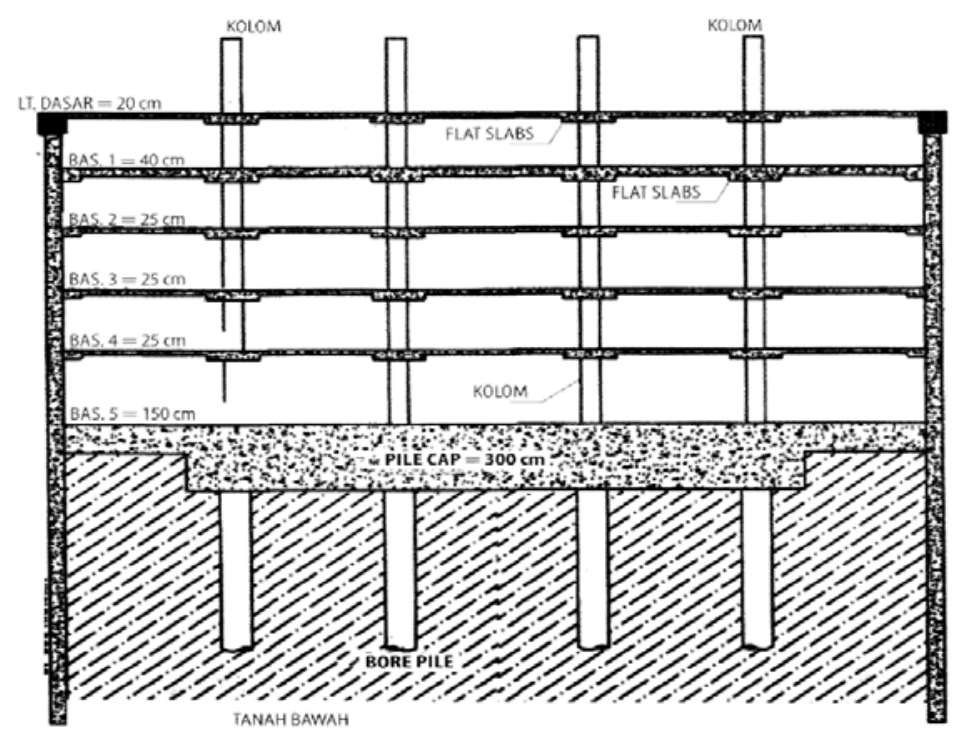

Gambar 3. Potongan basement dengan metode top-down (Sumber: Mistra, 2012)

\section{Analisis Construction Stage}

Pada analisis construction stage, tidak dibuat model analisis independen untuk setiap tahap konstruksi. Sebaliknya, digunakan konsep model kumulatif di mana hanya perubahan struktur atau pembebanan yang menjadi input untuk setiap tahap konstruksi dan hasil analisis diakumulasikan dari hasil analisis tahap sebelumnya. Digunakan prosedur analisis langkah demi langkah sesuai dengan penerapan beban mati secara sekuensial selama konstruksi berlangsung Oleh karena itu dalam analisis construction stage, perubahan struktur dan riwayat pembebanan dari tahap sebelumnya mempengaruhi hasil analisis tahap selanjutnya (Midas GTS, 2013).

\section{Analisis Konvensional}

Analisis konvensional dilakukan dengan asumsi bahwa semua beban diterapkan secara bersamaan ke struktur lengkap yang sudah jadi. Asumsi ini tidak valid dalam konstruksi nyata khususnya pada basement dengan metode top-down, karena konstruksi dilaksanakan secara bertahap dan beban mati yang bekerja juga diterapkan secara bertahap (Panigrahi, 2019).

\section{Syarat Batas Deformasi Lateral Dinding Penahan}

Batasan deformasi lateral izin dinding penahan tanah dan/atau embedded walls ditentukan oleh kondisi tanah, kedalaman galian serta jarak dan kondisi gedung terdekat yang besarnya ditentukan dalam rumusan seperti yang tercantum dalam Tabel 1 .

Tabel 1. Batas maksimum deformasi lateral dinding

\begin{tabular}{|c|c|c|c|c|}
\hline \multirow{3}{*}{$\begin{array}{l}\text { Batas maksimum deformasi } \\
\text { lateral pada dinding }\end{array}$} & \multicolumn{4}{|c|}{ Lokasi gedung dan infrastruktur eksisting terdekat } \\
\hline & \multirow{2}{*}{$\begin{array}{c}\text { Zona } 1 \\
(\mathrm{x} / \mathrm{H}<1)\end{array}$} & \multirow{2}{*}{$\begin{array}{c}\text { Zona } 2 \\
(1 \leq \mathrm{x} / \mathrm{H} \leq 2)\end{array}$} & \multicolumn{2}{|c|}{ Zona $3(\mathrm{x} / \mathrm{H}>2)$} \\
\hline & & & Tanah Tipe A & Tanah Tipe B \\
\hline $\begin{array}{l}\text { Batas izin maksimum } \\
\text { deformasi }(\delta \mathrm{w} / \mathrm{H})\end{array}$ & $0,5 \%$ & $0,7 \%$ & $0,7 \%$ & $1,0 \%$ \\
\hline
\end{tabular}

(Sumber: Badan Standardisasi Nasional, 2017)

Keterangan:

- $\mathrm{x}=$ jarak dari batas galian

- $\mathrm{H}=$ kedalaman galian

- $\delta \mathrm{w}=$ defleksi dinding

- Tanah Tipe A= tanah lempung dan lanau overconsolidated, tanah residual, dan tanah pasir dengan kepadatan sedang sampai dengan padat.

- Tipe Tanah $\mathrm{B}=$ tanah lempung dan lanau lunak, tanah organik dan tanah timbunan tidak terpadatkan. 


\section{METODE PENELITIAN}

\section{Prosedur Analisis}

Secara garis besar prosedur yang dilakukan dalam penelitian ini adalah sebagai berikut:

1. Tahap awal dari penelitian ini dimulai dengan menentukan data tanah dan layout bangunan dari proyek yang akan digunakan dalam penelitian.

2. Tahap berikutnya adalah mengolah data tanah yang telah didapat dengan menggunakan korelasi-korelasi.

3. Lalu dilakukan studi literatur mengenai tahapan-tahapan pekerjaan basement dengan metode top-down

4. Langkah berikutnya adalah pemodelan untuk tahapan-tahapan pekerjaan basement dengan metode top-down. Pemodelan dilakukan dengan program MIDAS GTS NX (pemodelan 3D).

5. Tahap berikutnya adalah dibuat perbandingan dengan pertama-tama dilakukan analisis construction stage, lalu dibandingkan dengan analisis konvensional tanpa memperhitungkan construction stage pada pemodelan.

6. Lalu dilakukan analisa hasil deformasi dinding diafragma.

7. Tahapan terakhir pada penelitian ini adalah membandingkan hasil yang didapat dari analisis. Kemudian akan diformulasikan kesimpulan-kesimpulan yang dapat bermanfaat untuk perencana.

Gambar 4 menunjukkan diagram alir penelitian.

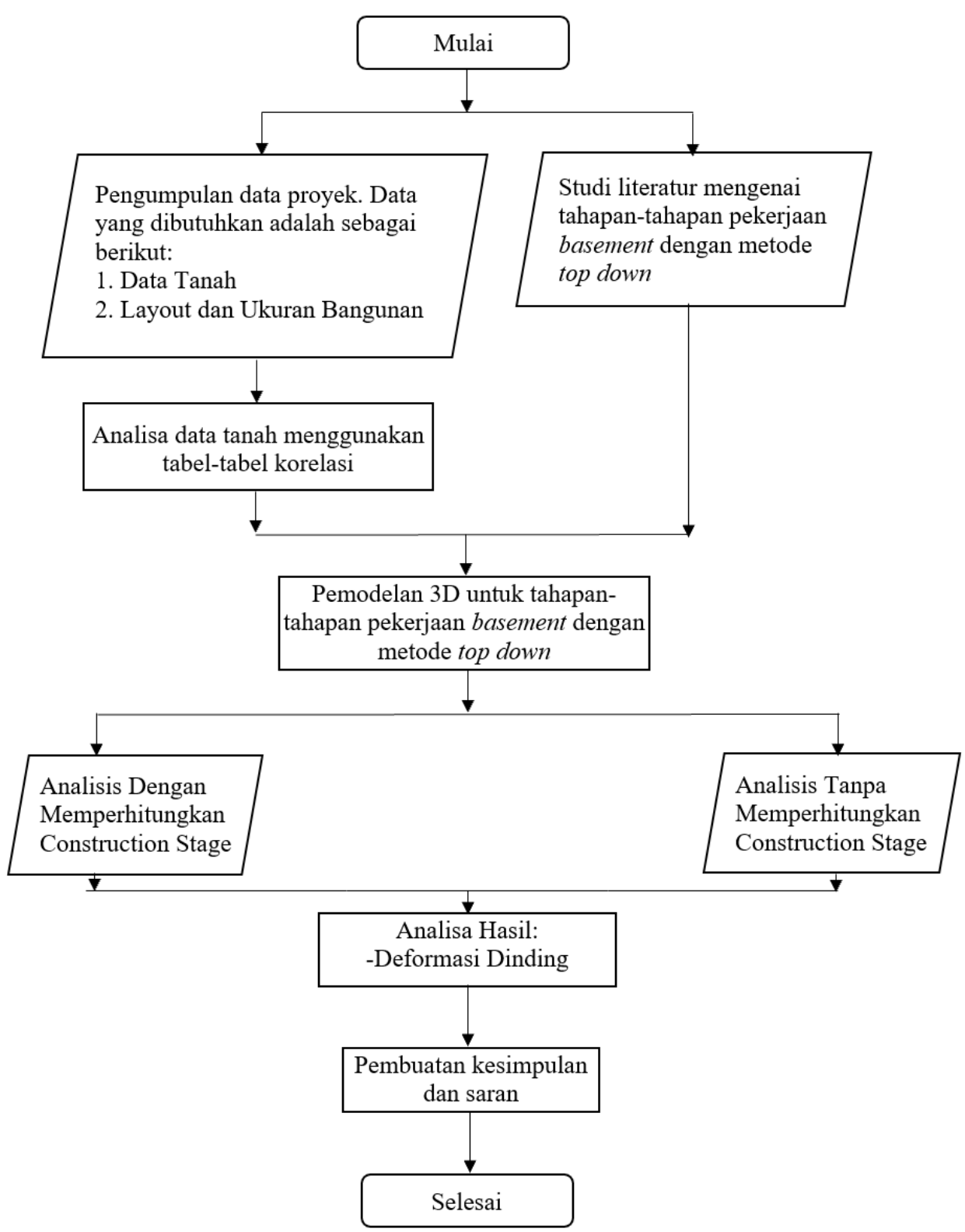

Gambar 4. Diagram alir penelitian 


\section{Tahapan Pemodelan}

Pada program MIDAS GTS NX, secara garis besar dilakukan tahapan pemodelan seperti pada Gambar 5.

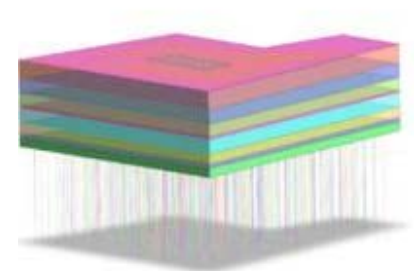

Pemodelan Geometri
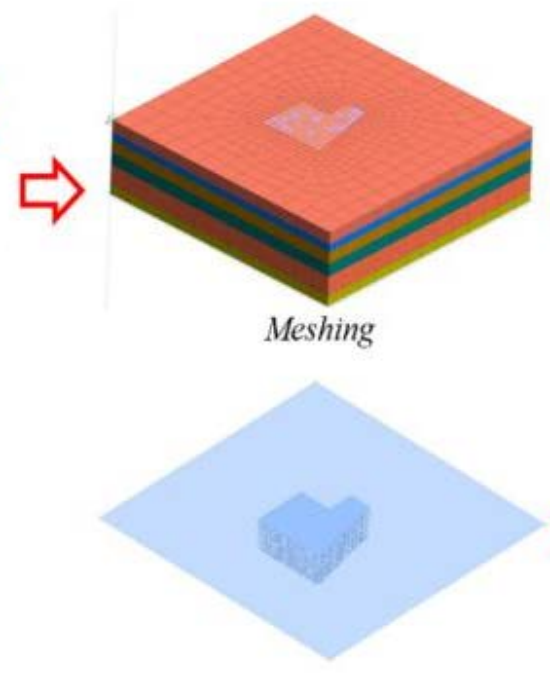

Menambahkan muka air

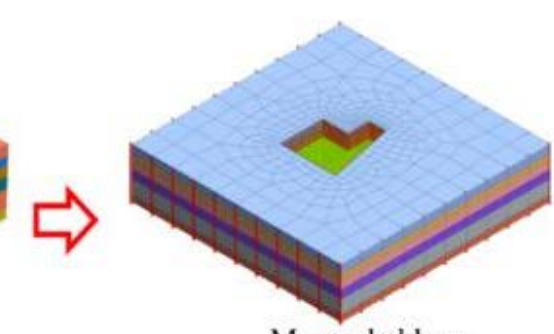

Menambahkan boundary condition

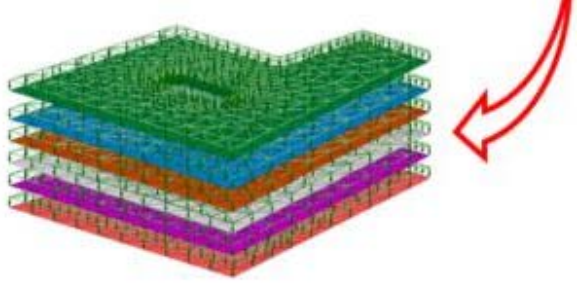

Menambahkan beban statik

Gambar 5. Tahapan pemodelan 3D pada MIDAS GTS NX

\section{Pemodelan Tanah}

Untuk pemodelan tanah, awalnya dibuat model geometri untuk tanah galian dan tanah luar galian. Tahap selanjutnya, dilakukan meshing seperti pada Gambar 6. Untuk input data tanah, pada menu material dipilih create isotropic lalu model type yang digunakan untuk tanah adalah modified mohr-coulomb. Lalu dimasukkan data tanah sesuai dengan data rekap Tabel 2 s.d. Tabel 4.
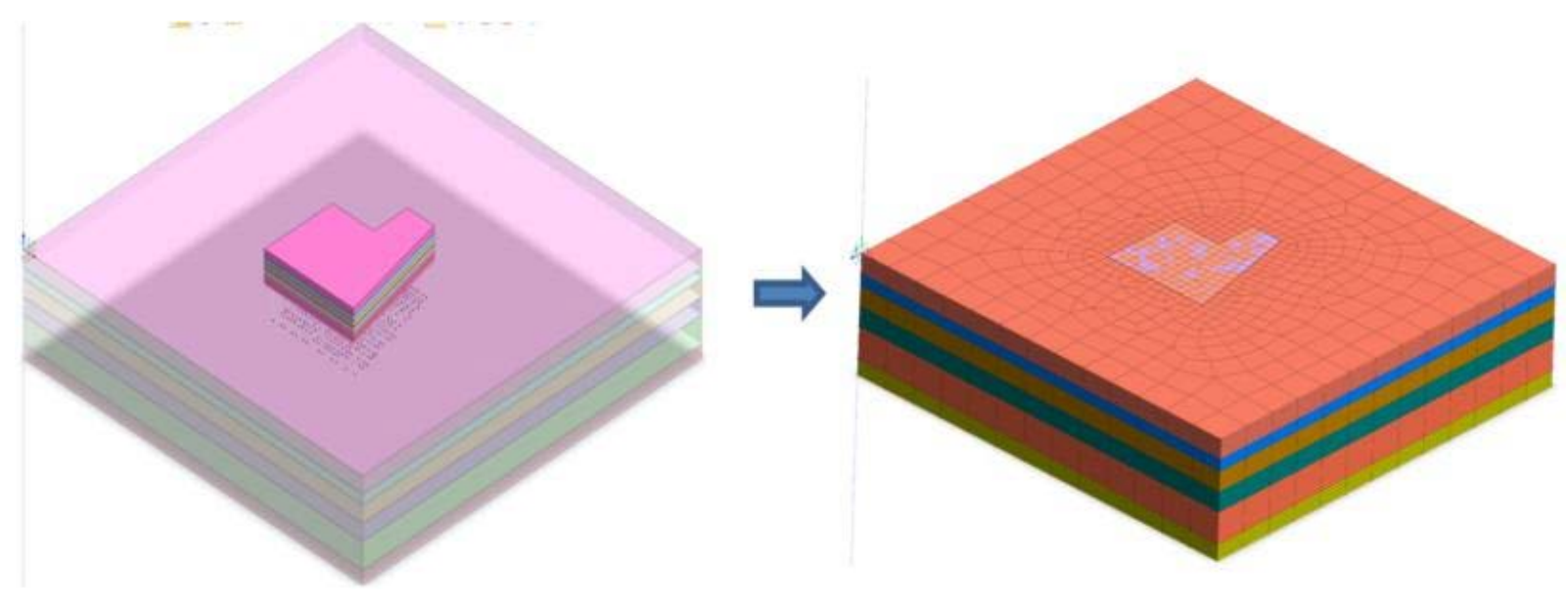

Gambar 6. Pemodelan geometri dan meshing tanah

\section{Pemodelan Dinding Diafragma dan Struktur Basement}

Letak titik tiang bor/king post diimport dari denah AutoCad. Lalu dilakukan pemodelan geometri dan meshing untuk dinding diafragma, pelat basement, raft, king post, dan tiang bor. Untuk dinding diafragma dan tanah, dibuat interface yang mewakili hubungan antarmuka dan begitu pula untuk tiang bor dan tanah. Hasil meshing pelat, dinding diafragma, king post, tiang bor dan interface antar dinding diafragma dan tanah diperlihatkan pada Gambar 7 berikut ini. 


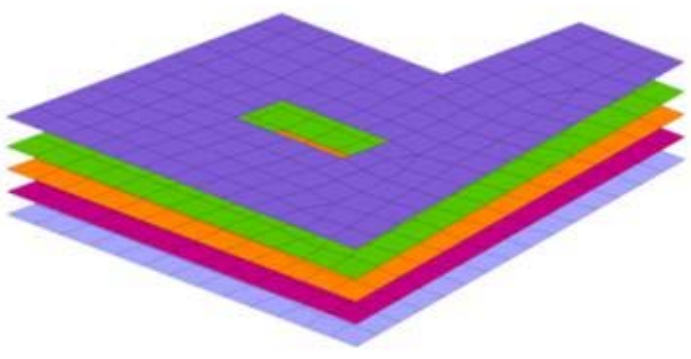

Pelat Lantai Basement

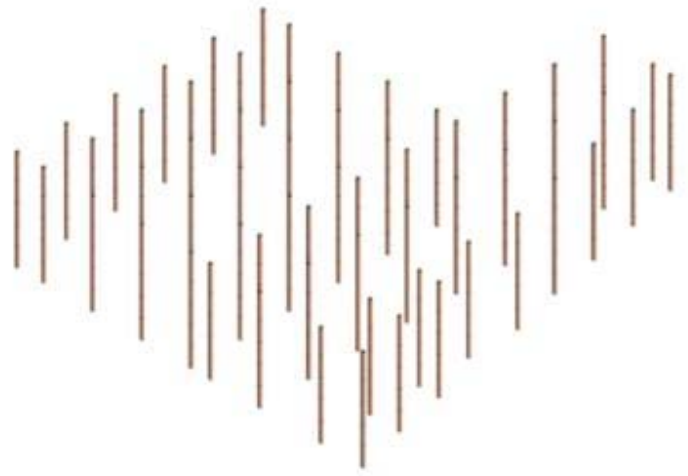

King Post

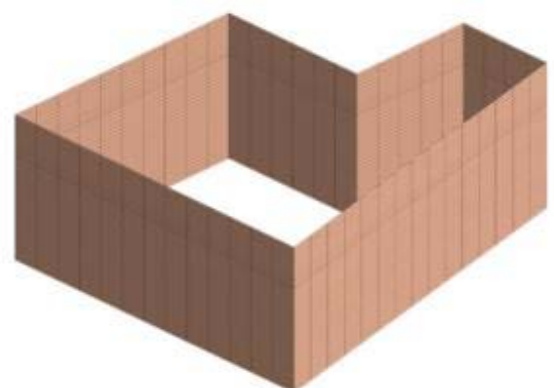

Dinding Diafragma

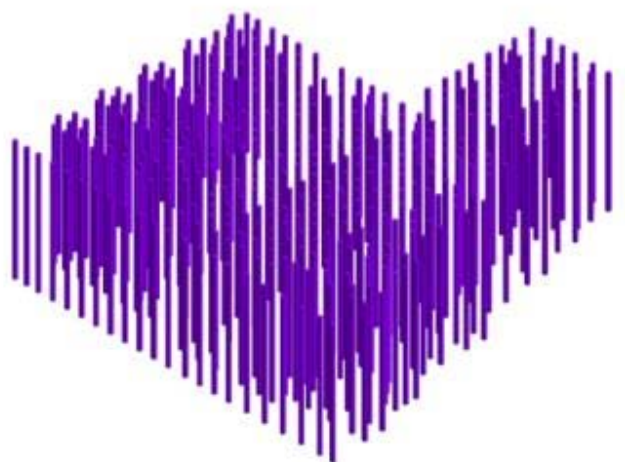

Tiang Bor

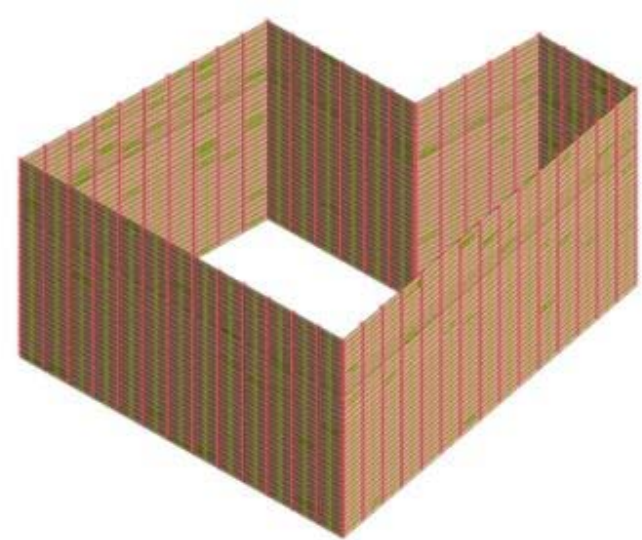

Interface Antar Dinding Diafragma \& Tanah

Gambar 7. Hasil meshing untuk dinding diafragma dan struktur basement

\section{Penambahan Kondisi Batas}

Setelah meshing, dilakukan penambahan kondisi batas untuk tanah dengan cara Static/Slope Analysis > Boundary > Constraint $>$ Auto. Lalu ditambahkan kondisi batas untuk tiang dan king post dengan cara Static/Slope Analysis $>$ Boundary > Constraint > Advanced Tab > Object type: Node > Select: Semua nodal tiang bor/ king post > DOF: Rz

\section{Penambahan Beban Statis}

Beban statis yang dipertimbangkan adalah beban parkir sebesar $4 \mathrm{kN} / \mathrm{m}^{2}$ yang diaplikasikan pada pelat basement, berat sendiri (self weight), surcharge load sebesar $10 \mathrm{kN} / \mathrm{m}^{2}$, dan beban dari struktur atas sesuai dengan pembebanan pada struktur atas yang diaplikasikan sebagai beban terpusat pada king post.

\section{Penambahan Muka Air}

Pada saat pemodelan ini dimasukkan letak muka air tanah sesuai dengan kedalaman. Pada luar area galian, MAT berada pada kedalaman $-1 \mathrm{~m}$. Sedangkan pada area galian, muka air tanah divariasikan. Muka air tanah pada area galian menurun sedalam 1 meter di bawah tanah yang sudah digali sesuai dengan tahapan galian yang berlangsung. 


\section{HASIL DAN PEMBAHASAN}

\section{Rekap Input Parameter Tanah}

Tipe model yang digunakan untuk tanah adalah modified mohr-coulomb dan analisis dilakukan pada kondisi drained. Tabel 2 s.d Tabel 6 memperlihatkan rekap input parameter tanah.

Tabel 2. Rekap input parameter tanah (1)

\begin{tabular}{cccccccc}
\hline $\begin{array}{c}\text { Lapisan } \\
\text { Tanah }\end{array}$ & $\begin{array}{c}\text { Kedalaman } \\
(\mathrm{m})\end{array}$ & $\begin{array}{c}\mathrm{N}- \\
\mathrm{SPT}\end{array}$ & Jenis Tanah & $\begin{array}{c}\text { Konsistensi } \\
\text { Tanah }\end{array}$ & $\begin{array}{c}\text { Poisson } \\
\text { Ratio }\end{array}$ & $\begin{array}{c}\gamma_{\text {unsat }} \\
\left(\mathrm{kN} / \mathrm{m}^{3}\right)\end{array}$ & $\begin{array}{c}\gamma_{\text {sat }} \\
\left(\mathrm{kN} / \mathrm{m}^{3}\right)\end{array}$ \\
\hline Lapisan 1 & $0-10$ & 10 & Clay & Medium & 0,35 & 15 & 17 \\
Lapisan 2 & $10-16$ & 20 & Clay & Stiff & 0,3 & 16 & 18 \\
Lapisan 3 & $16-26$ & 30 & Clay & Very Stiff & 0,3 & 17 & 19 \\
Lapisan 4 & $26-36$ & 40 & Clay & Very Stiff & 0,3 & 17 & 19 \\
Lapisan 5 & $36-52$ & 40 & Clay & Very Stiff & 0,3 & 17 & 19 \\
Lapisan 6 & $52-60$ & 40 & Clay & Hard & 0,2 & 18 & 20 \\
\hline
\end{tabular}

Tabel 3. Rekap input parameter tanah (2)

\begin{tabular}{cccccccc}
\hline Lapisan Tanah & Kedalaman $(\mathrm{m})$ & $\mathrm{e}_{0}$ & $\mathrm{~K}(\mathrm{~m} / \mathrm{sec})$ & $\mathrm{S}_{\mathrm{u}}(\mathrm{kPa})$ & $\mathrm{E}(\mathrm{MPa})$ & $\mathrm{E}_{\text {oed }}(\mathrm{MPa})$ & $\mathrm{E}_{\text {uref }}(\mathrm{MPa})$ \\
\hline Lapisan 1 & $0-10$ & 1,3 & $10^{-7}$ & 20 & 10 & 16 & 30 \\
Lapisan 2 & $10-16$ & 1 & $10^{-7}$ & 30 & 20 & 30 & 60 \\
Lapisan 3 & $16-26$ & 0,8 & $10^{-7}$ & 50 & 30 & 40 & 90 \\
Lapisan 4 & $26-36$ & 0,8 & $10^{-7}$ & 80 & 40 & 54 & 120 \\
Lapisan 5 & $36-52$ & 0,8 & $10^{-7}$ & 80 & 40 & 54 & 120 \\
Lapisan 6 & $52-60$ & 0,8 & $10^{-7}$ & 100 & 40 & 44 & 120 \\
\hline
\end{tabular}

Tabel 4. Rekap input parameter tanah (3)

\begin{tabular}{ccccccc}
\hline Lapisan & Kedalaman $(\mathrm{m})$ & Porositas $(\mathrm{n})$ & $\phi\left(^{(}\right)$ & $\Psi\left(^{(}\right)$ & $\mathrm{C}(\mathrm{kPa})$ & OCR \\
\hline Lapisan 1 & $0-10$ & 0,57 & 18 & 0 & 10 & 2 \\
Lapisan 2 & $10-16$ & 0,50 & 20 & 0 & 20 & 1,4 \\
Lapisan 3 & $16-26$ & 0,44 & 23 & 0 & 36 & 1,4 \\
Lapisan 4 & $26-36$ & 0,44 & 25 & 0 & 36 & 1,4 \\
Lapisan 5 & $36-52$ & 0,44 & 25 & 0 & 36 & 1,2 \\
Lapisan 6 & $52-60$ & 0,44 & 30 & 0 & 50 & 1,2 \\
\hline
\end{tabular}

\section{Rekap Input Spesifikasi Dinding Penahan Tanah}

Tabel 5 memperlihatkan rekap input parameter dinding diafragma.

Tabel 5. Rekap input spesifikasi dinding diafragma

\begin{tabular}{cccc}
\hline Parameter & Nama & Nilai & Satuan \\
\hline Jenis Perilaku & Jenis Material & Elastis & - \\
Modulus elastisitas & $\mathrm{E}$ & $2,7 \times 10^{7}$ & $\mathrm{kN} / \mathrm{m}^{2}$ \\
Tebal ekivalen & $\mathrm{t}$ & 1 & $\mathrm{~m}$ \\
Berat & $\mathrm{kN} / \mathrm{m}^{3}$ \\
Angka Poisson & $v$ & 24 & - \\
\hline
\end{tabular}




\section{Rekap Input Spesifikasi Pelat}

Tabel 6 memperlihatkan rekap input parameter pelat (slab).

Tabel 6. Rekap input spesifikasi pelat (slab)

\begin{tabular}{cccc}
\hline Parameter & Nama & Nilai & Satuan \\
\hline Jenis Perilaku & Jenis Material & Elastis & - \\
Modulus elastisitas & $\mathrm{E}$ & $2,7 \times 10^{7}$ & $\mathrm{kN} / \mathrm{m}^{2}$ \\
Tebal ekivalen & $\mathrm{t}$ & 0,3 & $\mathrm{~m}$ \\
Berat & $\gamma$ & 24 & $\mathrm{kN} / \mathrm{m}^{3}$ \\
Angka Poisson & $v$ & 0,18 & - \\
\hline
\end{tabular}

\section{Rekap Input Spesifikasi Raft}

Tabel 7 memperlihatkan rekap input parameter raft.

Tabel 7. Rekap input spesifikasi raft

\begin{tabular}{cccc}
\hline Parameter & Nama & Nilai & Satuan \\
\hline Jenis Perilaku & Jenis & Elastis & - \\
Modulus elastisitas & $\mathrm{E}$ & $2,7 \times 10^{7}$ & $\mathrm{kN} / \mathrm{m}^{2}$ \\
Tebal ekivalen & $\mathrm{t}$ & 2 & $\mathrm{~m}$ \\
Berat & $\mathrm{V}$ & 24 & $\mathrm{kN} / \mathrm{m}^{3}$ \\
Angka Poisson & $v$ & 0,18 & - \\
\hline
\end{tabular}

\section{Rekap Input Spesifikasi Tiang Bor}

Tabel 8 memperlihatkan rekap input parameter tiang bor pada tabel berikut.

Tabel 8. Rekap input spesifikasi tiang bor

\begin{tabular}{cccc}
\hline Parameter & Nama & Nilai & Satuan \\
\hline Jenis Perilaku & Jenis & Elastis & - \\
Modulus elastisitas & $\mathrm{E}$ & $2,7 \times 10^{7}$ & $\mathrm{kN} / \mathrm{m}^{2}$ \\
Diameter & $\mathrm{D}$ & 0,8 & $\mathrm{~m}$ \\
Berat & $\gamma$ & 24 & $\mathrm{kN} / \mathrm{m}^{3}$ \\
Angka Poisson & $v$ & 0,18 & - \\
\hline
\end{tabular}

\section{Rekap Input Spesifikasi King post}

Tabel 9 memperlihatkan rekap input parameter king post.

Tabel 9. Rekap input spesifikasi king post

\begin{tabular}{cccc}
\hline Parameter & Nama & Nilai & Satuan \\
\hline Jenis Perilaku & Jenis Material & Elastis & - \\
Modulus elastisitas & E & $2 \times 10^{8}$ & $\mathrm{kN} / \mathrm{m}^{2}$ \\
Berat & $\mathrm{V}$ & 76,98 & $\mathrm{kN} / \mathrm{m}^{3}$ \\
Angka Poisson & $\mathrm{v}$ & 0,3 & - \\
\hline
\end{tabular}

King post menggunakan pipa baja 600 mm dengan tebal 50 mm. 


\section{Perbandingan Tegangan Vertikal Dan Horizontal Efektif Pada Program Dan Hitungan Manual}

Pengecekan dilakukan dengan membandingkan tegangan vertikal efektif dan tegangan horizontal efektif antara perhitungan manual dan hasil dari program. Analisis dilakukan pada tahap galian akhir dengan MAT luar galian berada pada kedalaman -1 m dan MAT area galian pada kedalaman -18 m. Gambar 8 dan Gambar 9 menunjukkan perbandingan antara kedua hasil. Tabel 10 menunjukkan hasil perhitungan manual tegangan aktif dan pasif.

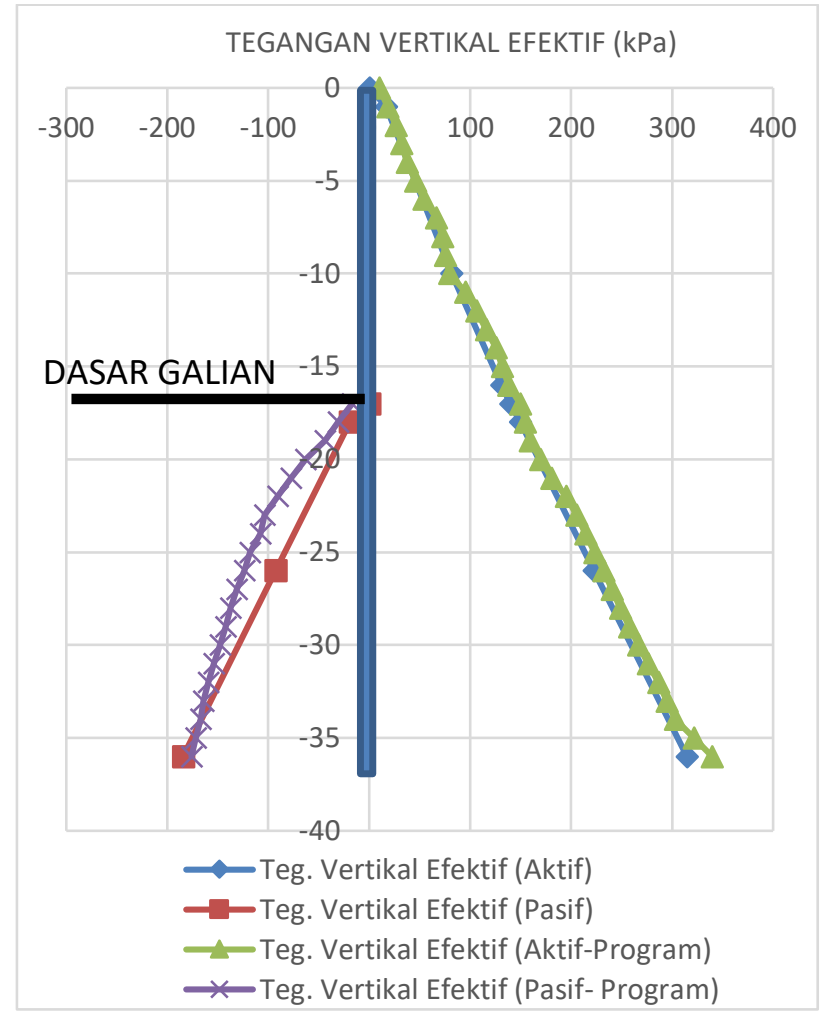

Gambar 8. Tegangan Vertikal Efektif (Program Vs Hitungan Manual)

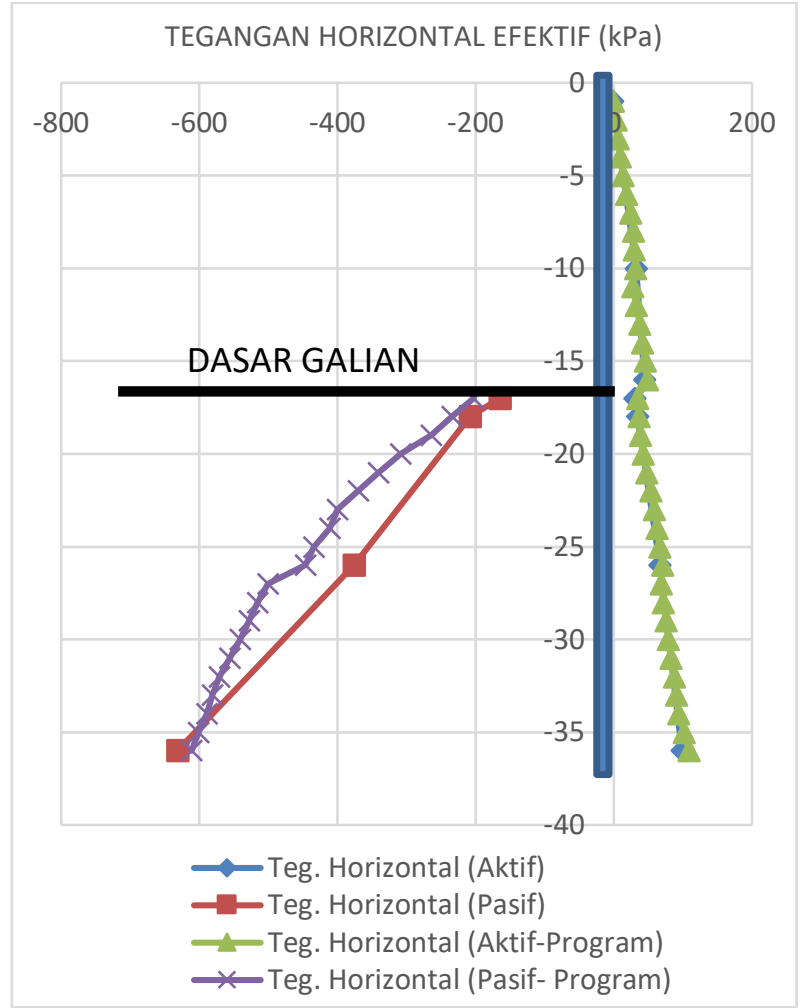

Gambar 9 Tegangan Horizontal Efektif (Program Vs Hitungan Manual)

Tabel 10. Hasil perhitungan manual tegangan efektif

\begin{tabular}{|c|c|c|c|c|c|c|c|c|c|c|c|}
\hline \multirow{2}{*}{$\begin{array}{l}\text { Kedalaman } \\
\text { (m) }\end{array}$} & \multirow{2}{*}{$\begin{array}{c}\gamma \\
\left(\mathrm{kN} / \mathrm{m}^{3}\right)\end{array}$} & \multirow{2}{*}{$C^{\prime}$} & \multirow{2}{*}{$\varphi^{\prime}$} & \multicolumn{2}{|c|}{ Koefisien } & \multicolumn{2}{|c|}{$\begin{array}{l}\text { Teg. Vertikal } \\
\text { Efektif (kPa) }\end{array}$} & \multirow{2}{*}{$2 c^{\prime} \mathrm{Ka}$} & \multirow{2}{*}{$2 c^{\prime} \mathrm{Kp}$} & \multicolumn{2}{|c|}{$\begin{array}{l}\text { Teg. Lateral } \\
\text { Efektif (kPa) }\end{array}$} \\
\hline & & & & $\begin{array}{c}\text { Aktif } \\
(\mathrm{Ka})\end{array}$ & $\begin{array}{l}\text { Pasif } \\
(\mathrm{Kp})\end{array}$ & Aktif & Pasif & & & Aktif & Pasif \\
\hline 0 & 0 & & & & & 0.00 & & & & & \\
\hline 1 & 17 & 10 & 18 & 0,53 & 1,89 & 17,00 & & 10,56 & $-37,89$ & $-1,58$ & \\
\hline 10 & 17 & 10 & 18 & 0,53 & 1,89 & 81,71 & & 10,56 & $-37,89$ & 32,57 & \\
\hline 16 & 18 & 20 & 20 & 0,49 & 2,04 & 130,8 & & 19,61 & $-81,58$ & 44,54 & \\
\hline 17 & 19 & 36 & 23 & 0,44 & 2,28 & 140,0 & 0,00 & 31,54 & $-164,35$ & 29,81 & $-164,35$ \\
\hline 18 & 19 & 36 & 23 & 0,44 & 2,28 & 149,2 & $-19,00$ & 31,54 & $-164,35$ & 33,83 & $-207,72$ \\
\hline 26 & 19 & 36 & 23 & 0,44 & 2,28 & 222,7 & $-92,52$ & 31,54 & $-164,35$ & 66,04 & $-375,54$ \\
\hline 36 & 19 & 36 & 25 & 0,41 & 2,46 & 314,6 & $-184,42$ & 29,22 & $-177,40$ & 98,48 & $-631,80$ \\
\hline
\end{tabular}

\section{Hasil Analisis Construction Stage}

Dari hasil analisis construction stage, bisa didapatkan deformasi maksimum dinding penahan tanah pada masingmasing arah X dan Y seperti pada Gambar 10. 

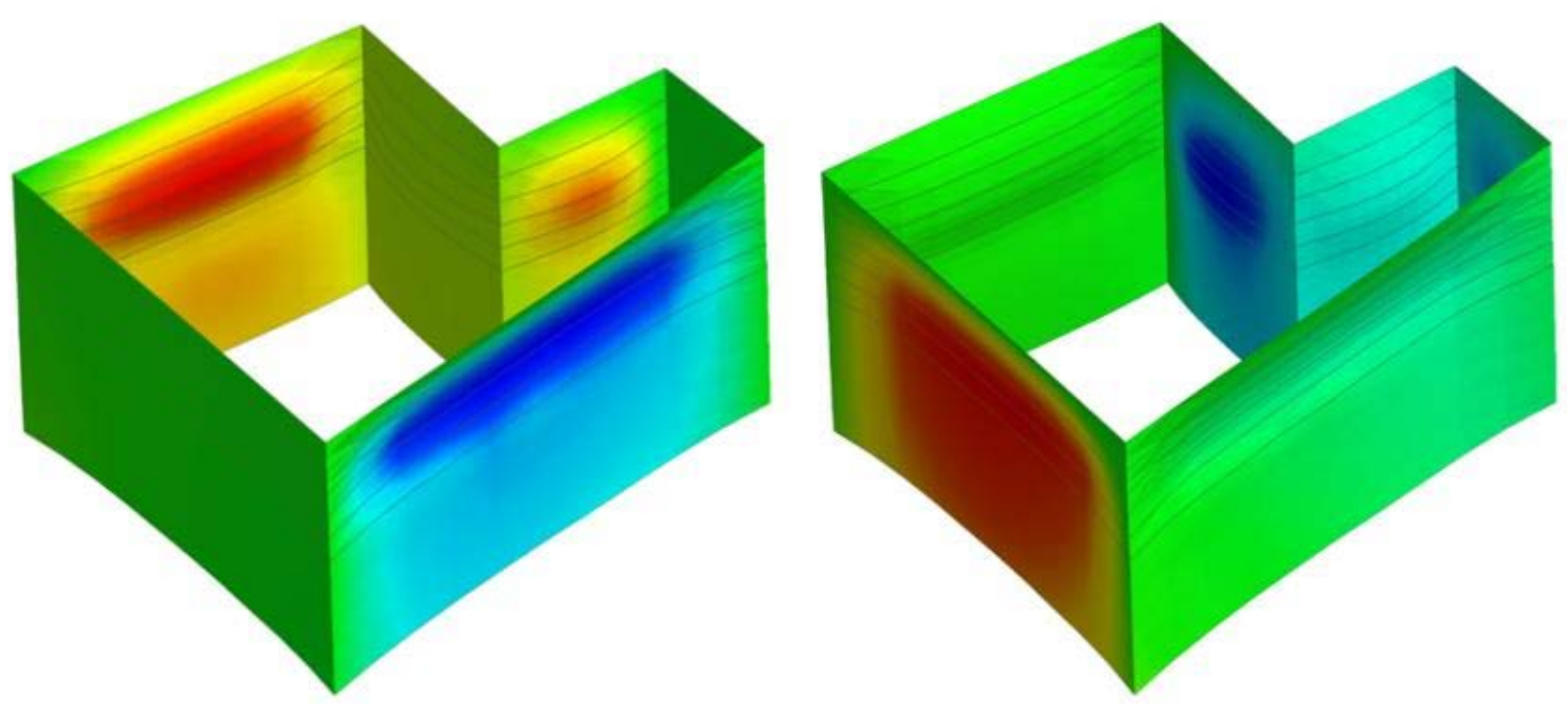

Gambar 10. Deformasi dinding arah x (kiri) dan arah y (kanan)

Tabel 11. Perbandingan deformasi maksimum dinding diafragma dengan pelat dan tanpa pelat

\begin{tabular}{ccccc}
\hline \multirow{2}{*}{ Tahapan } & \multicolumn{2}{c}{ Deformasi Max Arah X $(\mathrm{mm})$} & \multicolumn{2}{c}{ Deformasi Max Arah Y $(\mathrm{mm})$} \\
\cline { 2 - 5 } & Dengan Pelat & Tanpa Pelat & Dengan Pelat & Tanpa Pelat \\
\hline Tahap Awal & 0,00 & 0,00 & 0,00 & 0,00 \\
Instalasi & 0,00 & 0,00 & 0,00 & 0,00 \\
Pemasangan Pelat 1 & 0,00 & - & 0,00 & - \\
Penggalian Tahap 1 & 7,43 & 16,16 & 5,74 & 11,32 \\
Pemasangan Pelat 2 & 7,38 & - & 5,69 & - \\
Penggalian Tahap 2 & 10,31 & 28,55 & 8,32 & 19,41 \\
Pemasangan Pelat 3 & 10,28 & - & 8,29 & - \\
Penggalian Tahap 3 & 12,30 & 49,49 & 10,28 & 27,19 \\
Pemasangan Pelat 4 & 12,30 & - & 10,27 & - \\
Penggalian Tahap 4 & 13,92 & 97,34 & 12,06 & 35,82 \\
Pemasangan Pelat 5 & 13,95 & - & 12,07 & - \\
Penggalian Tahap 5 & 14,96 & 177,34 & 13,44 & 44,20 \\
Pemasangan Raft & 15,07 & 179,11 & 13,57 & 45,23 \\
\hline
\end{tabular}

Untuk memperoleh gambaran seberapa efektif fungsi pelat sebagai strut, dilakukan perbandingan antara deformasi maksimum dengan pelat sebagai strut dan tanpa pelat sebagai strut.

Batas maksimum deformasi ditetapkan dalam SNI Geoteknik sesuai dengan Tabel 1. Diasumsikan bahwa $\mathrm{x} / \mathrm{H}<1$, sehingga batas maksimum deformasi sebesar $0.5 \% \mathrm{H}$ yaitu $85 \mathrm{~mm}$. Deformasi dinding penahan tanah dengan pelat masih memenuhi syarat SNI. Namun, tidak sama halnya dengan deformasi dinding penahan tanah tanpa perkuatan pelat sehingga pelat diperlukan selama pekerjaan penggalian agar dinding penahan tanah dalam keadaan aman.

Dari hasil analisis pada Tabel 11, dapat dilihat bahwa perbedaan hasil deformasi maksimum antara penggalian basement tanpa pelat sebagai strut dan penggalian basement dengan pelat sebagai strut sangat besar. Pada tahap galian 5, didapatkan deformasi maksimum sebesar 15,07 mm (dengan perkuatan pelat) dan 179,11 mm (tanpa perkuatan pelat). Didapat perbedaan sebesar 164,04 mm.

Hasil deformasi dinding pada masing-masing tahapan dapat dilihat pada Gambar 11 untuk penggalian dengan perkuatan pelat dan Gambar 12 untuk penggalian tanpa perkuatan pelat.

Pada Gambar 11 dan Gambar 12, dapat terlihat perbedaan pola. Pada model tanpa pelat, letak titik deformasi maksimumnya selalu terletak di bagian paling atas dinding pada tiap tahapan, sedangkan pada model dengan pelat, letak titik deformasi maksimumnya berpindah-pindah. Semakin dalam galian, letak titik deformasi maksimumnya semakin ke bawah. 
Perbandingan Deformasi Dinding pada Basement Metode Top-Down dengan Analisis Construction Stage dan Analisis

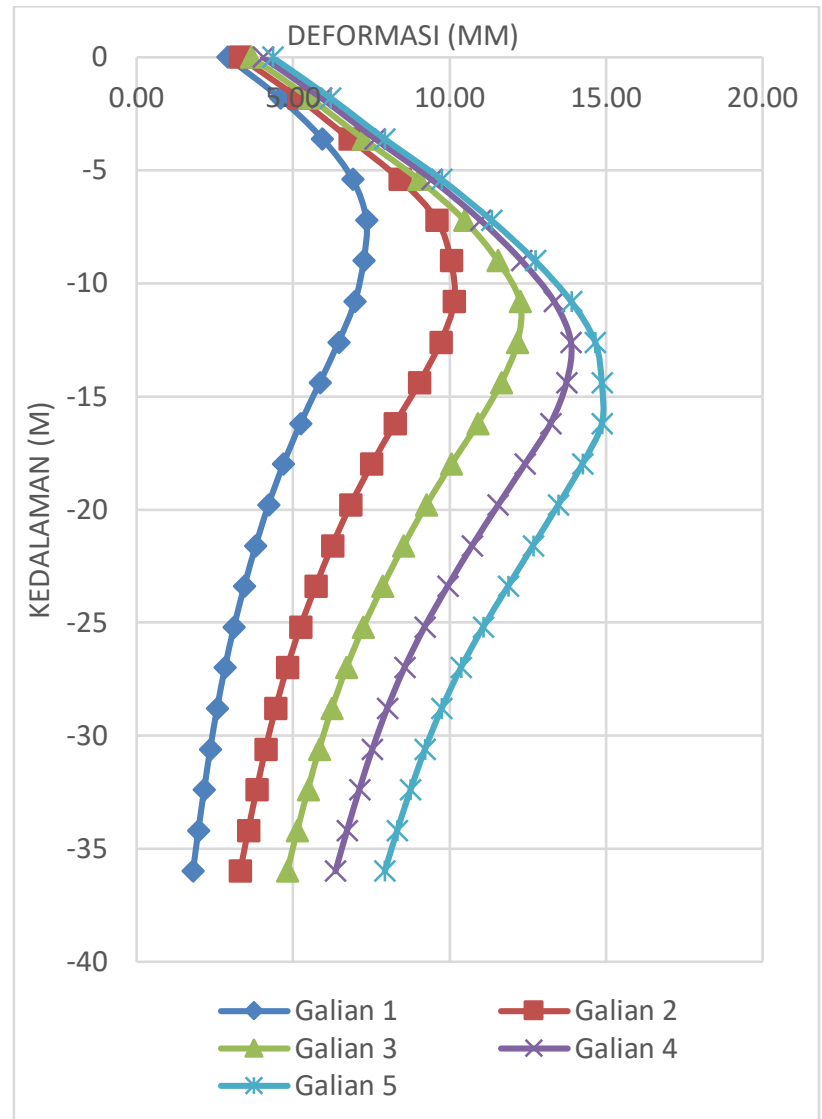

Gambar 11. Grafik deformasi dinding (dengan pelat) pada tiap tahap galian

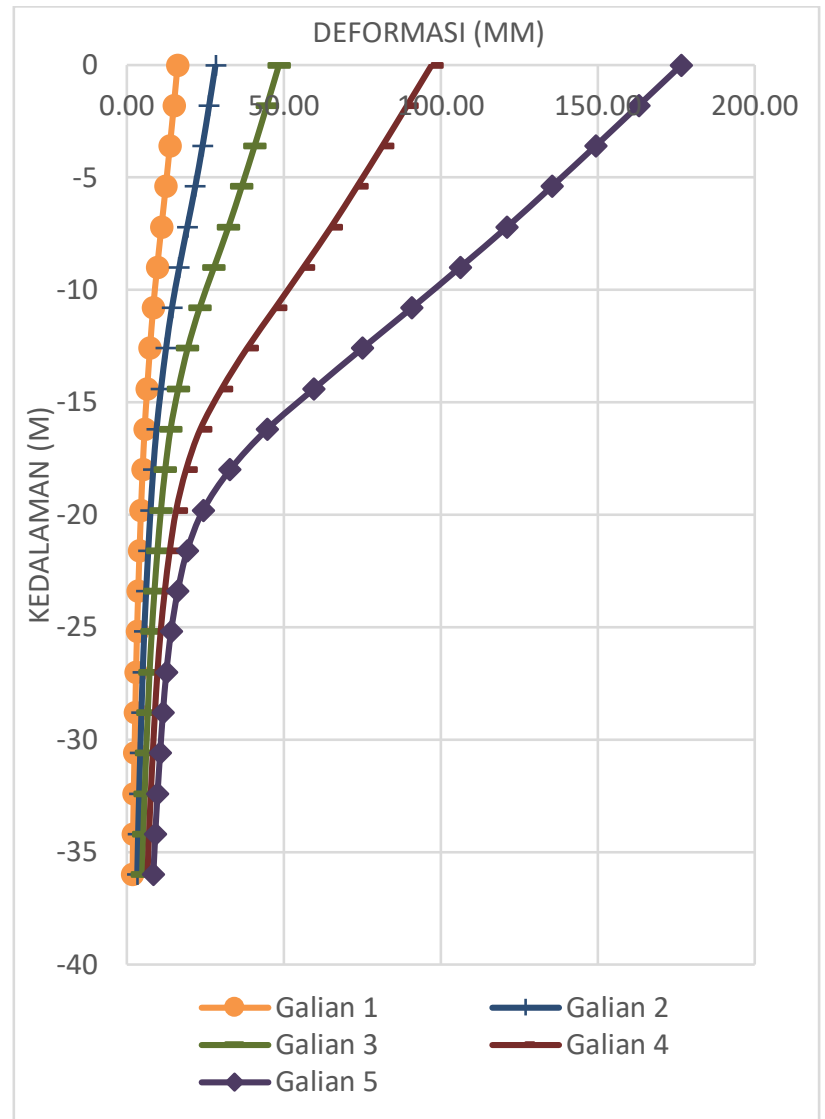

Gambar 12. Grafik deformasi dinding (tanpa pelat) pada tiap tahap galian

\section{Perbandingan Antara Hasil Analisis Construction Stage dan Analisis Konvensional}

Selanjutnya dilakukan perbandingan hasil deformasi antara analisis construction stage dan analisis biasa (tanpa memperhitungkan construction stage). Hasil deformasi maksimum ditabulasikan pada Tabel 12.

Tabel 12. Perbandingan hasil deformasi maksimum dinding antara analisis construction stage dan analisis konvensional

\begin{tabular}{cccc}
\hline \multirow{2}{*}{ Tahapan Konstruksi } & \multicolumn{2}{c}{ Deformasi Max Dinding Diafragma (mm) } & \\
\cline { 2 - 3 } & \multicolumn{2}{c}{ Analisis } & $\begin{array}{c}\text { Perbedaan } \\
(\mathrm{mm})\end{array}$ \\
& $\begin{array}{c}\text { Dengan } \\
\text { Memperhitungkan }\end{array}$ & $\begin{array}{c}\text { Tanpa } \\
\text { Temperhitungkan } \\
\text { Tahapan Kontruksi }\end{array}$ & \\
\hline Tahap Awal & 0,00 & 0,00 & 0,00 \\
Instalasi & 0,00 & 0,00 & 0,00 \\
Penggalian Tahap 1 & 7,43 & 6,84 & 0,59 \\
Penggalian Tahap 2 & 10,31 & 7,86 & 2,45 \\
Penggalian Tahap 3 & 12,30 & 8,68 & 3,62 \\
Penggalian Tahap 4 & 13,92 & 9,08 & 4,84 \\
Penggalian Tahap 5 & 14,96 & 9,36 & 5,60 \\
\hline
\end{tabular}

Dari tabel di atas, jelas terlihat bahwa deformasi dengan memperhitungkan tahapan konstruksi lebih besar daripada deformasi tanpa memperhitungkan tahapan konstruksi. Perbedaan tidak terlalu besar pada tahap galian 1 yaitu 0,59 mm. Namun perbedaan semakin besar pada tahap-tahap berikutnya hingga mencapai perbedaan sebesar 5,60 mm pada tahap galian 5. Maka dari itu, pengaruh dari tahapan konstruksi tidak dapat diabaikan khususnya pada pekerjaan basement dengan metode top-down. 
Pada Gambar 13 dan Gambar 14, ditunjukkan grafik deformasi pada masing-masing tahapan. Gambar 13 menggambarkan deformasi dinding hasil analisis construction stage, sedangkan Gambar 14 menggambarkan deformasi dinding hasil analisis konvensional.

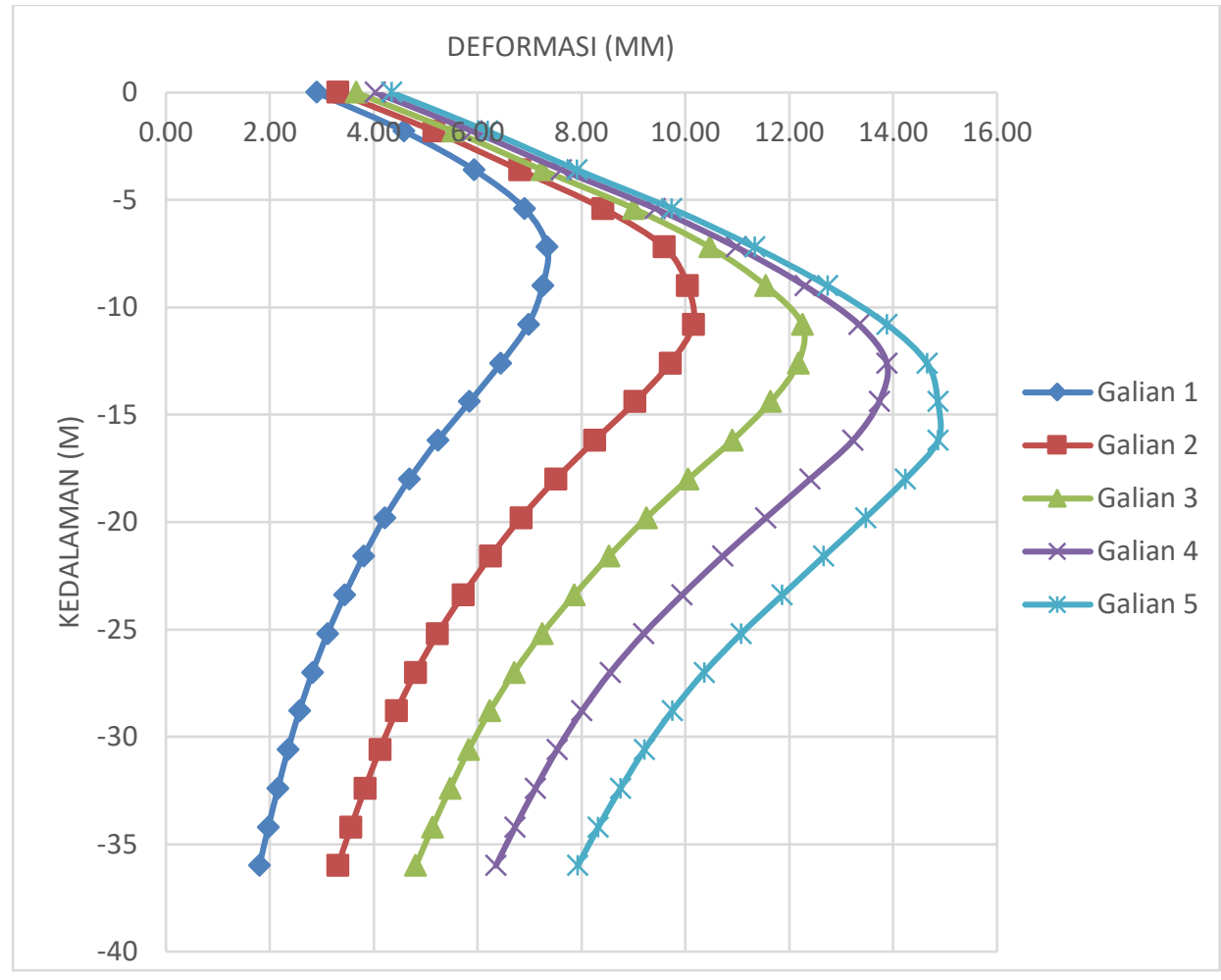

Gambar 13. Hasil deformasi dinding dengan analisis construction stage

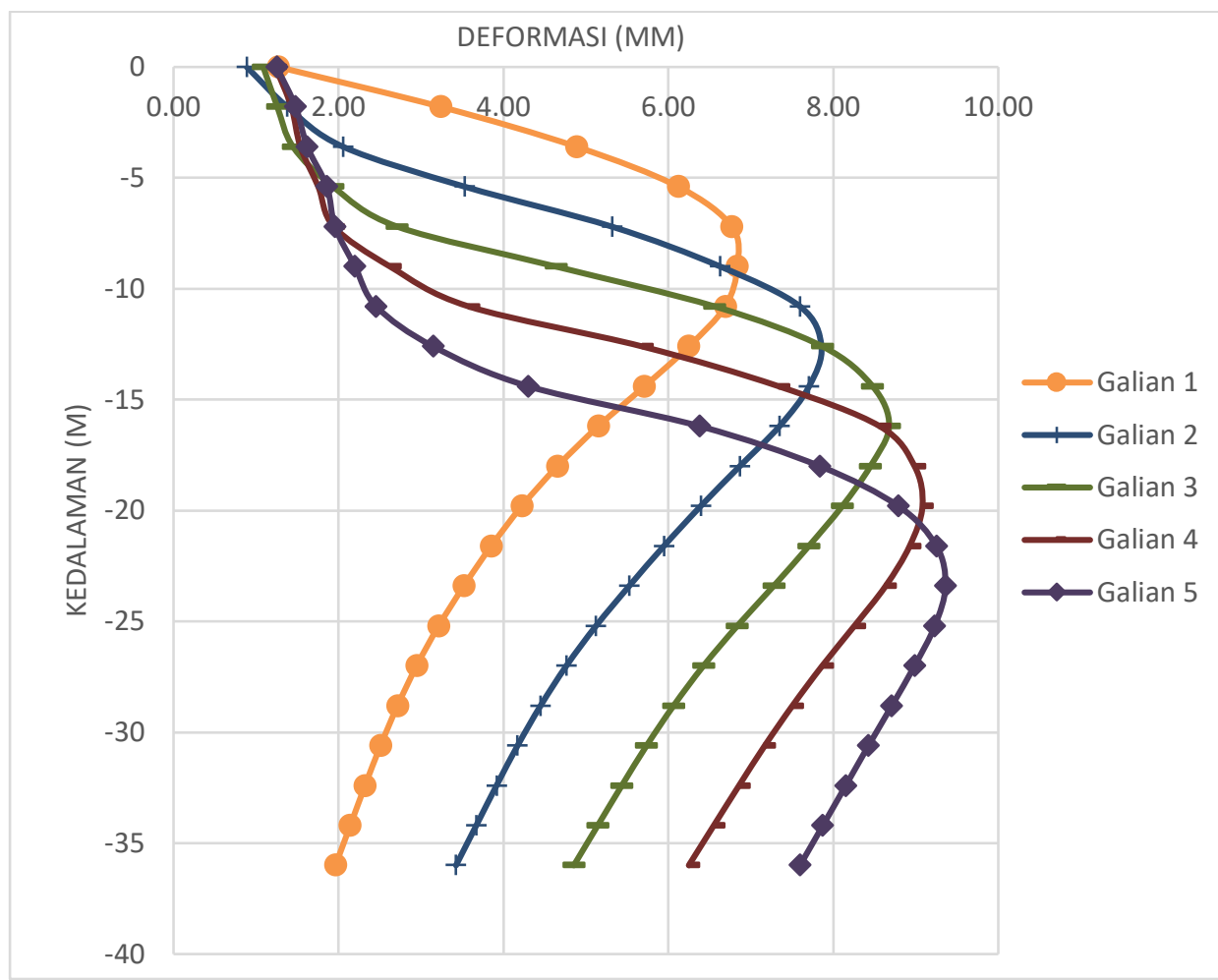

Gambar 14. Hasil deformasi dinding dengan analisis konvensional 
Perbandingan Deformasi Dinding pada Basement Metode Top-Down dengan Analisis Construction Stage dan Analisis Konvensional

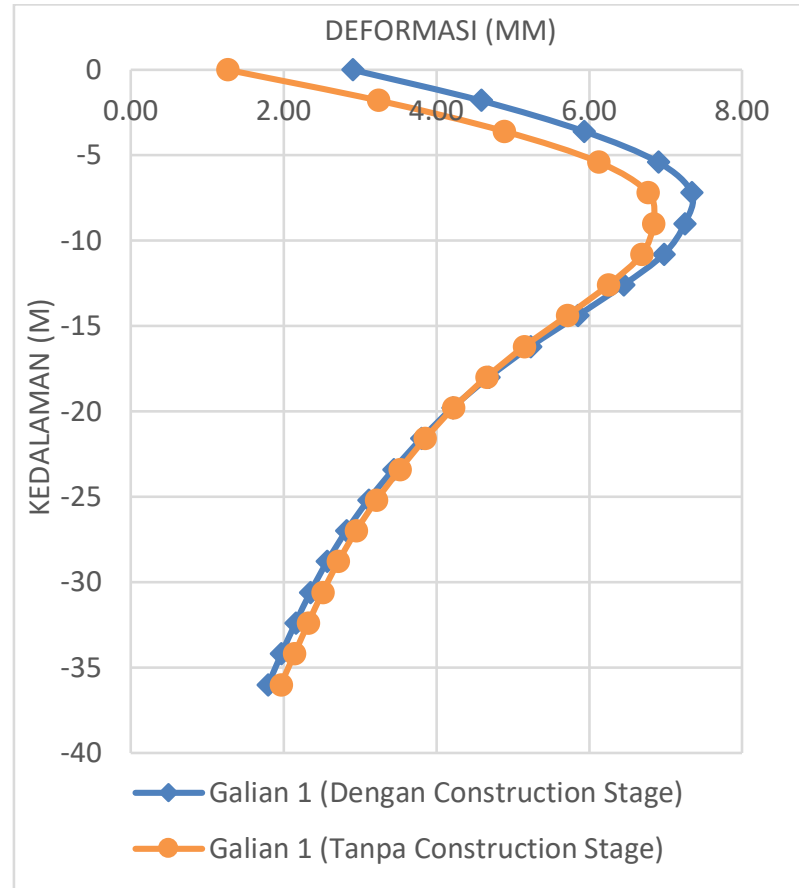

Gambar 15. Perbandingan hasil deformasi dinding antara analisis construction stage dan analisis konvensional pada galian tahap 1

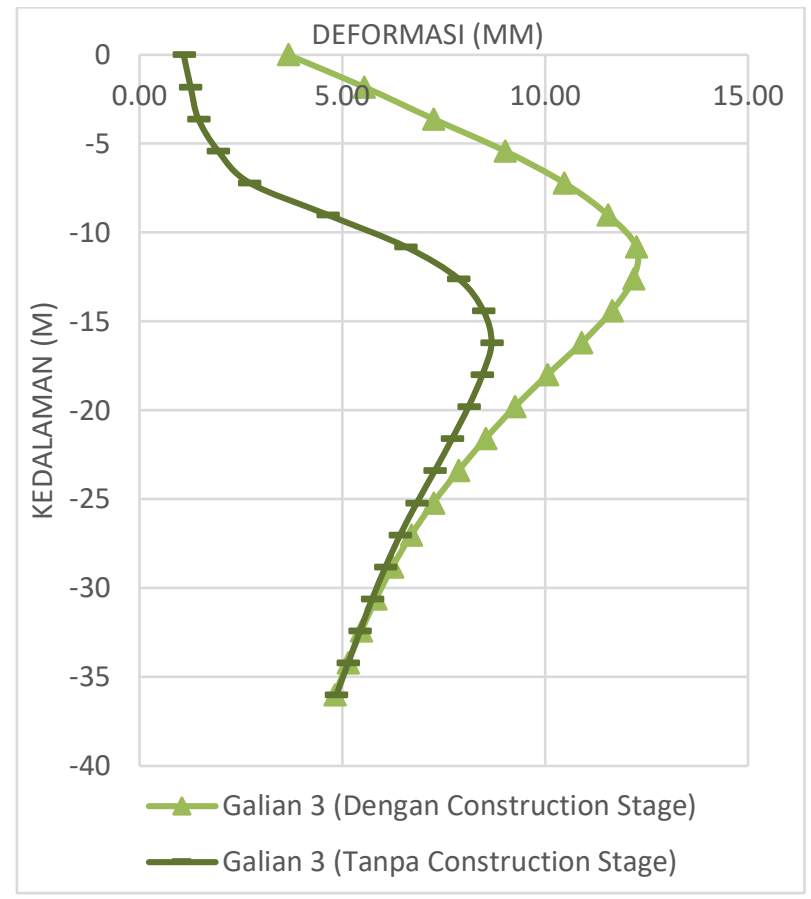

Gambar 17. Perbandingan hasil deformasi dinding antara analisis construction stage dan analisis konvensional pada galian tahap 3

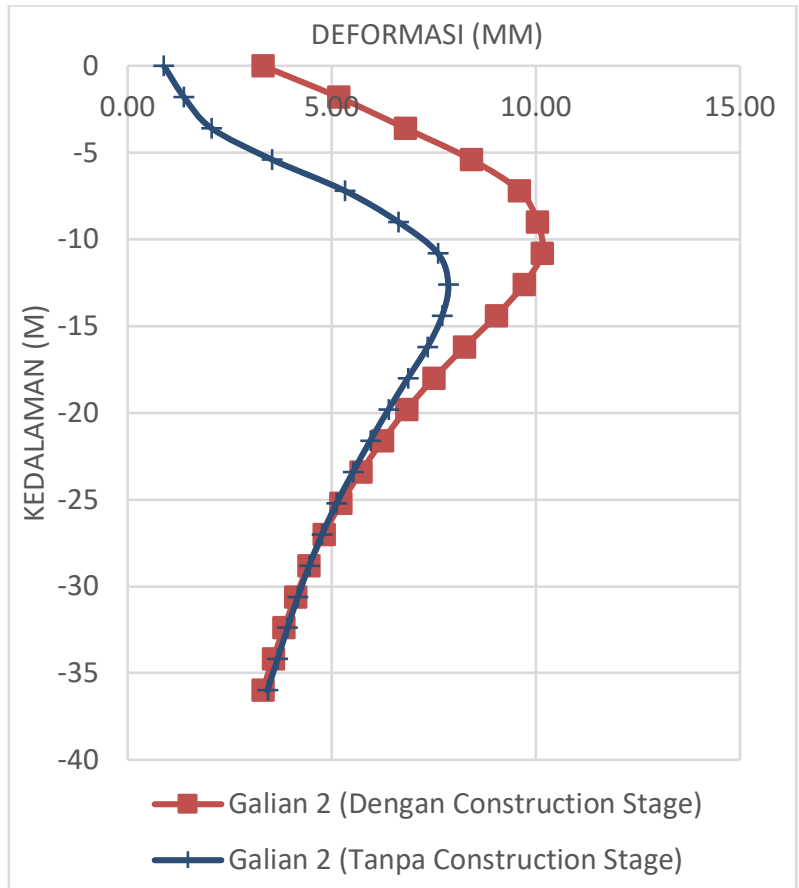

Gambar 16. Perbandingan hasil deformasi dinding antara analisis construction stage dan analisis konvensional pada galian tahap 2

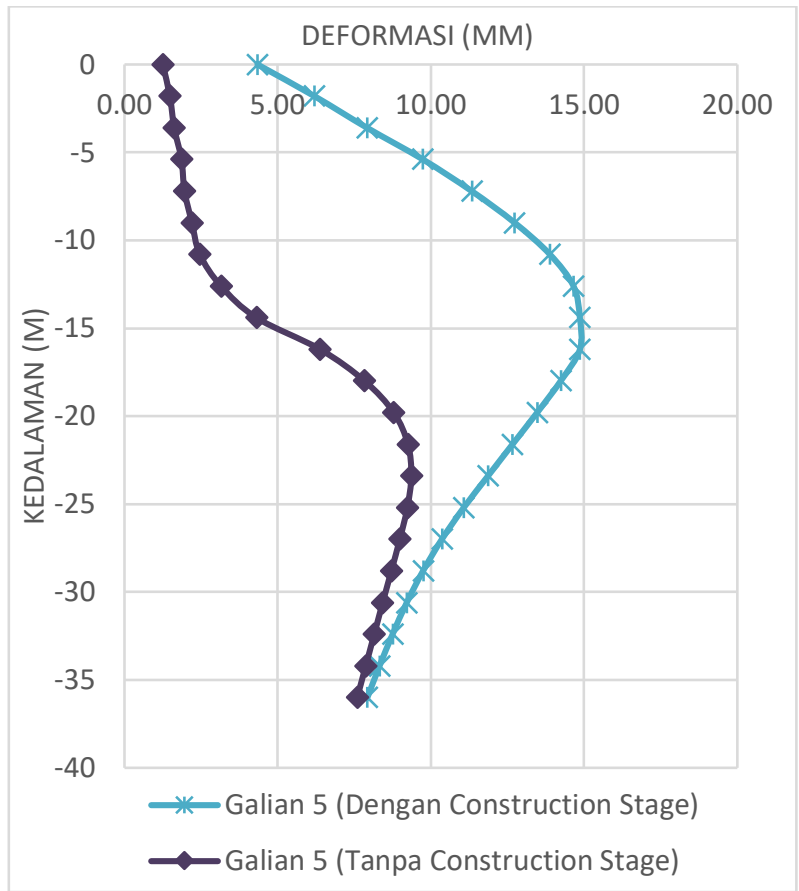

Gambar 18. Perbandingan hasil deformasi dinding antara analisis construction stage dan analisis konvensional pada galian tahap 5

Pada Gambar 15 s.d. Gambar 18, dilakukan perbandingan dalam bentuk grafik agar memperjelas perbedaan tren. Dilihat dari Gambar 15, hasil deformasi dinding pada tahap galian 1 mempunyai tren pergerakan yang sama dan nilai yang tidak jauh berbeda. 
Namun seiring dengan maju nya tahapan, dapat dilihat pada Gambar 18 bahwa perbedaan tren semakin terlihat dan nilai semakin jauh berbeda. Hal ini jelas menunjukkan bahwa pengaruh tahapan konstruksi sebaiknya tidak diabaikan karena mempengaruhi hasil analisis khususnya apabila basement cukup dalam.

\section{KESIMPULAN DAN SARAN}

Berdasarkan hasil analisis yang telah dilakukan dengan analisis construction stage dan analisis konvensional, didapatkan kesimpulan sebagai berikut:

- Pada pekerjaan basement dengan metode top-down, penting untuk dilakukan construction stage analysis karena berpengaruh terhadap hasil analisis.

- Hasil deformasi dinding menunjukkan bahwa hasil analisis construction stage lebih besar dibanding analisis biasa (tanpa memperhitungkan tahapan konstruksi) sehingga lebih baik desain dihitung menggunakan tahapan konstruksi sesuai dengan yang terjadi di lapangan.

- Dari hasil analisis construction stage pada basement dengan sistem top-down, didapatkan bahwa deformasi maksimum yang terjadi pada dinding semakin besar seiring dengan majunya tahapan konstruksi.

- Pelat berfungsi sangat efektif sebagai strut pada sistem top-down dan membantu menahan beban lateral tanah sehingga mengurangi defleksi dinding penahan tanah (dinding diafragma). Pada penggalian basement tanpa pelat sebagai strut, didapatkan deformasi dinding penahan tanah sebesar 179,11 mm pada tahap galian 5 , namun apabila pelat digunakan deformasi berkurang menjadi 15,07 mm yaitu 8,41\% dari deformasi dinding tanpa pelat.

- Deformasi maksimum dinding diafragma terjadi pada tahap galian $5+$ raft. Deformasi ini masih lebih kecil daripada syarat deformasi sesuai ketentuan SNI yaitu sebesar 85 mm

Berdasarkan hasil analisis yang telah dilakukan, adapun saran untuk melengkapi studi ini adalah:

- Pada saat melakukan meshing dapat dibuat dengan lebih detail lagi agar hasil yang didapat lebih akurat.

- Elemen struktur yang belum dilihat gaya-gaya dalam yang terjadi dapat ditampilkan di analisis berikutnya.

- Untuk analisis selanjutnya disarankan untuk memperhitungkan perubahan muka air tanah di luar area galian yang terjadi.

\section{DAFTAR PUSTAKA}

Badan Standardisasi Nasional. Persyaratan perancangan geoteknik. SNI 8460 (2017), 2017.

Das, G. "Comparison of Conventional and Construction." IJSTE - International Journal of Science Technology \& Engineering (2016): 1.

Midas GTS. “NX On-line Manual.” Finite Element Analysis For Geotechnical Engineering. 2013.

Mistra, H. Struktur Dan Konstruksi Bangunan Tinggi Sistem Top and Down. Jakarta: Griya Kreasi, 2012.

Panigrahi, Santosh. “Importance of Construction Sequence Analysis.” IJISET - International Journal of Innovative Science, Engineering \& Technology (2019): 1-3.

Prawidiawati, Fitri. “ANALISA PERBANDINGAN METODE BOTTOM-UP DAN METODE TOP-DOWN PEKERJAAN BASEMENT PADA GEDUNG PARKIR APARTEMEN SKYLAND CITY EDUCATION PARK BANDUNG DARI SEGI BIAYA DAN WAKTU.” JURNAL TEKNIK POMITS (2015): 1-6.

Xiao, Hongju. "Case Study of Top-Down Construction." EJGE (2016). 
Perbandingan Deformasi Dinding pada Basement Metode

Raynaldi, et al.

Top-Down dengan Analisis Construction Stage dan Analisis

Konvensional 